\title{
THE WHEAT PROBLEM IN U.S.S.R.
}

\author{
V. P. Timoshento

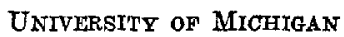

The actual and the potential competition in the world markets for agricultural products on the part of Russia may be appraised only in an historical perspective. Russia and the United States were the largest exporters of agricultural products, particularly of grain, for many decades preceding the World War. Their competition was especially acute on the grain market-particularly on the wheat market-and it developed with changing success for both countries: from the 1870's to the end of the previous century the United States increased its relative position on the European grain market; from the beginning of the twentieth century, during the years preceding the World War, Russia regained to some extent its preponderant position on the wheat market, when America under the influence of the growing interior market receded to second place (or even as far as third place if one takes into consideration Argentine wheat exports).

Characteristic of Russian exports during several decades preceding the World War was the very great importance of the grain exports in the total value of Russian exports. Beginning from the seventies of the previous century, the value of the grain export composed more than a half of the total value of exports. With the development of some other branches of agricultural exports such as exports of eggs, butter, and flax fiber, the relative importance of the grain exports declined a little but it always continued to be, up to the World War, on the level of 45 to 50 per cent of the total value of exports and in absolute value it was rapidly growing: from the 1890's of the previous century to the last years before the War, the value of Russian grain exports about doubled. In this field Russian competition was particularly acute for the United States, while other important branches of Russian agricultural exports (such as eggs, butter, flax, and hemp fiber ${ }^{1}$ ) did not compete with the United States exports, because the United States was not an exporter of these products. As to the exports of meat, Russia always was rather a weak competitor on the international market; it could not acquire for its meat a large foreign market.

However, in spite of a rapid growth of the Russian grain

1 Which in 1909-13 composed about one-third of the value of Russian grain exports. 
exports during the last decades before the War, its relative importance in comparison to the growing interior market for grain was rather declining. The comparatively rapid industrialization of Russia which took place during the last decades before the War resulted in a faster growth of interior markets for agricultural products. The tendency was the same as for the United States, though less pronounced. The declining rôle of the exports in percentage of the total production for two principal breadgrains may be seen from the tabulation below:

\section{EXPORTS OF WHEAT AND RYE FROM RUSSIAN EMPIRE IN PER CENT OF THEIR TOTAL PRODUCTION \\ (On the territory of 72 provinces)}

\begin{tabular}{ccc}
\hline Years & Wheat & Rye \\
\hline $1895-1900$ & 26.6 & 6.7 \\
$1901-1905$ & 24.1 & 6.6 \\
$1906-1910$ & 22.8 & 4.0 \\
$1909-1913$ & 21.6 & 3.4 \\
\hline
\end{tabular}

During a period of about twenty years, the export of wheat declined from one-fourth to one-fifth of the total production, while practically all rye was used for home consumption, with the exception of a small percentage, and during two years this percentage declined one-half. Among other principal grains, only barley exports did not decline during the decades just preceding the War. Barley after wheat was the second important export grain of Russia competing on the European markets with American corn. The favorable tariff policy of Germany for feed barley was responsible for a very rapid development of Russian exports of barley, during the decades just prior to the War, when barley successfully competed on German markets with corn, particularly since 1906 when German custom duties on barley were fixed lower comparatively to the duties on corn. About twofifths of the total Russian erop of barley was exported.

Thus Russian wheat and barley were the principal products competing with American exports in western Europe. Exports of wheat and barley were rapidly increasing during the last decades prior to the war and they replaced there, to some degree, American wheat and corn, which were more and more used for home consumption, although, for Russian wheat the interior Russian market also became of much greater importance relative to the foreign market.

Such was the situation at the outbreak of the World War, which suddenly stopped Russian grain exports and opened large fields for the expansion of grain production outside of Europe, 
particularly in North America. The great expansion of wheat acreage in the United States and Canada was in a great part destined to cover the absence from the west European market of Russian wheat. The Russian revolution and civil war during 1917-1920 prolonged this situation for several years after the War when Russian grain completely disappeared from the world market until 1923. Furthermore, during 1921-22 Russia itself was obliged to import American relief grain.

Russian grain exports were resumed after 1923 but they were much smaller and still less stable than grain exports from the Russian Empire before the War. Instability was always characteristic of Russian grain exports. During the 22 years immediately preceding the War, the average deviation of wheat exports in percentage of the average exports for the whole period was 32 per cent. Not seldom from one year to another exports rose three or four times to be down a year or two later in the same proportion.

Russian wheat exports fluctated much more with the fluctuation of the yield than American exports, which affected the world wheat prices. Russian wheat exports dominated world wheat prices before the war more than exports from any other country as was shown in one of my previous studies. ${ }^{2}$

But the pre-war grain exports from Russia, though fluctuating greatly, did not fall below some minimum quantity, even in the poorest years. It is otherwise with the post-war grain exports from Soviet Russia. It is not only much smaller than the pre-war exports but it became intermittent: only in the years of a good yield do there exist exports of grain from Soviet Russia, while in the years with average or below average yields Russian grain exports cease. After the recovery of exports in 1923-24, grain exports disappear during 1924-25. They recover once more during 1925-26 and 1926-27 when wheat exports attained to from one-fourth to one-third of the pre-war, to disappear once more for three years from 1927-28 to 1929-30. Exports of wheat appear in larger quantity during 1930-31, because the yield of 1930 was exceptionally good as the result of weather conditions especially favorable for crops. Now, in 1931-32, we see once more a decline of the grain exports from Soviet Russia and it is difficult to say how large it would be for the whole current agricultural year. The question arises why are Russian grain exports

\footnotetext{
2 See V. P. Timoshenko, "Wheat Prices and the World Wheat Market." Memoir 118, Cornell University Agrioultural Experiment Station, Ithaca, N.Y. Revised edition, 1930, pp. 27-32.
} 
so low and so unstable since the revolution and what exports may be expected from Soviet Russia for the next years and for the more distant future? Are the exports small and unstable because production becomes smaller and less stable, or because interior consumption increased? And what are the tendencies for the future as to the possible growth of the production and the consumption and what will be the resultant from their exports?

It is a very difficult problem to make a comparison of the prewar and of the post-war crop statistics of Russia. Very cautious and scrupulous statistical criticism of both sets of data (the prewar and the post-war) is necessary as to methods of collection and of publication. It is necessary to say that very often insufficient attention is paid to the problem of the comparability of the pre-war and the post-war crop statistics of Russia. Often official pre-war crop statistics as they were published originally, adjusted only to the new frontier of the U.S.S.R., are compared with the post-war crop statistics communicated by official sources of Soviet Russia and conclusions are drawn directly from such a comparison. Such a comparison leaves, generally, an impression that since 1925 the production of grain in Soviet Russia was as large as or larger than it was immediately before the War and then different explanations are tried to explain why exports are so small.

But these statistics are incomparable as is clearly and openly recognized by official statisticians from such an official institution of Soviet Russia as the State Planning Committee (Gosplan). They consider the pre-war crop statistics an underestimated (in the crop area as well as in the yield per acre) and they correct generally the total grain production of pre-war Russia by increasing it by about 20 per cent. With such a correction the prewar and the post-war statistics become more comparable. Not all professional statisticians in Russia recognize that the prewar official crop statistics need to be corrected, but if they have to be used in their original values, then there is no other way to make the two sets of statistics comparable than to lower the post-war crop estimates.

Comparing the total grain production (of all kinds of grains) in Soviet Russia during the years 1925-28 with the pre-war grain production on the same territory, official statisticians of the Gosplan estimate that during these four years, which may be characterized as good or average years, it was on the average 
about 91 to 92 per cent of the pre-war $(1913=100)$. It fluctuated from 89 per cent in 1928 to 96 per cent in 1926. ${ }^{3}$ Thus, according to official (presumably still a little optimistic) estimates, in no one of these years was the grain production of Soviet Russia on the level of the pre-war grain production. On the average for four years it was from 8 to 9 per cent below the pre-war level. The condition in 1929 was not better. Only for 1930 do the official crop statisties show the grain area about equal to the pre-war level (99.5 per cent) and the total grain production above the prewar, because the yield was very good. Thus before 1930-31 the exports were low first because the grain production had not recovered the pre-war level.

But the grain production on the average for 1925-28 was given in official statistics as smaller by only from 8 to 9 per cent, while the pre-war exports of all grains composed (for 1909-13) about 13.5 per cent of the total production; therefore with the prewar size of consumption even such smaller production would leave about 5 per cent of the total grain crop for exports, while only during 1925-26 and 1926-27 it was about 3 to 4 per cent of the total production, and since 1927-28 to 1929-30 grain exports practically disappeared. For this fact may be responsible the growth of the interior consumption of grain. The interior consumption grew not because the per capita consumption of grain increased as was sometimes stated by Soviet statisticians, but simply because the population, during the period 1925-28, was substantially larger than the pre-war population on the same territory. The Census of December 17, 1926, enumerated on the actual territory of the U.S.S.R. 147 millions of population, while on January 1, 1914 the best estimates of the population for the same territory vary from 138 to 140 millions, ${ }^{4}$ that is, population in 1926 was from 5 to 6.5 per cent larger. The statisticians of the Gosplan, making a comparison of the per capita production of grain during 1925-28 with the pre-war per capita production, arrive at the conclusion that on the average, for the period 1925-28, per capita production of grain in the U.S.S.R. composed only about 85 to 86 per cent of the pre-war, that is, from 14 to 15 per cent below the pre-war, while the pre-war exports of all grains composed only about 13.5 per cent of the total production. Thus, even with the complete absence of grain exports, the per

\footnotetext{
"See "Control Figures of the National Economy of the U.S.S.R. for 1928-29," published by the Gosplan, Moscow, 1929 , pp. $408-412$ and note on p. 414 .

- See as to estimate of the population on January 1,1914 the Statistical Yearbook for 1918 1920 published by the Central Statistical Office, Moscow; also Oontrol Figures of National Economy of the U.S.S.R. for 1929-30, Moscow, 1930, p. 436 .
} 
capita consumption of grain could not be on the pre-war level during 1925-28. But, as was mentioned above, about 3 to 4 per cent of the total grain production was exported during 1925-26 and 192627. This lowers the per capita consumption still more. Since 1926 the population has continued to grow rapidly in the U.S.S.R. The birth rate was the same or only a little higher than the prewar, but the death rate after 1922 declined below the pre-war. One of the reasons for this may be that severe privations during the civil war and the famine of 1921-22 resulted in a very high death rate during that period and only the stronger people survived the strain of these years. On the other hand, the children's death rate, which was extremely high in the pre-war Russia, declined somewhat after 1922. As a result the growth of population in the U.S.S.R. was statistically estimated for 1924-27 to be about 2 per cent per year, or a little more. By 1929-30 the official estimate of the population of the U.S.S.R. was 158.5 millions..$^{5}$ That is from 13 to 15 per cent larger than it was before the War. If during the last years the growth of population was the same (about which we have no data) the population of Soviet Russia must be now about 20 per cent above the pre-war. In such a condition the grain production on the prewar level (which, according to official statistics, it reached to 1930) can not give any surplus for exports. On the contrary, even without any exports per capita consumption would be below the pre-war. No wonder that in such a case only exceptionally good yield may give some surplus of grain for export or the interior consumption has to be limited by some rationing system as has existed since 1928-29 in order to have exportable grain.

Under such conditions the increase of grain exports from Soviet Russia is possible only with a considerable growth of grain production in comparison with the pre-war. But what are the possibilities for such a growth? They may be manifold in the direction of: (a) an expansion of the crop area on new unoccupied lands; (b) a better utilization of the occupied crop area on account of a decrease of area of idle arable lands (fallow or temporary pasture); (c) replacement by grain of other than grain crops; and (d) an increase of the yield per acre. All these possibilities have to be analyzed from the point of view of short and long periods.

It is a largely accepted opinion that Russia has unlimited possibilities for an extensive expansion of grain production on

"See "Control Figures for 1929-30," p. 436. 
new unoccupied lands. However, this opinion is based only on a superficial analysis of Russian geographical and natural conditions. The expansion of arable area in the European part of Russia is very near to its limit. The process of the occupation of arable area in European Russia was practically completed before the war. During the last decade before the War the growth of the crop area was rapid only in the southeastern corner of European Russia (North Caucasus). In other parts of European Russia it was slower than the growth of population (even in the southern steppe area). During recent years-1929-31-it was possible to expand considerably the crop area in the southeastern area of Soviet Russia (North Caucasus, Trans-Volga region) only because during the post-revolution years, particularly since the famine of 1921, the crop area here declined much below the pre-war level.

Unoccupied lands good for crop production without special improvement, are still available only in Asiatic Russia, in Siberia, and in Central Asia, but even there the possibilities are much more limited than they are often presented. During twenty years preceding the World War the flow of colonists from European Russia to Asiatic Russia was so rapid that perhaps 6 millions of population crossed the Ural Mountains from European Russia during these twenty years, several hundred thousand of colonists per year. These colonists occupied the larger part of the land fitted for crop production in Asiatic Russia. It is necessary to say that in Siberia only a limited area (mostly in southwestern Siberia) is well fitted for crop production. Because of climatic conditions, the rest is not good for crops. The same must be said about Central Asia where the largest area is dry prairie or desert. Maybe only from one-eighth to one-ninth of the total Asiatic area may be considered as well fitted for crops, and the best agricultural regions were well populated by the flow of colonists before the War. Those regions of Siberia in which lands may be used for agriculture just as they are, without considerable and expensive preparatory work, are actually populated as densely as, or more densely, than the best agricultural regions of the United States. All specialists on the colonization problem in Russia are of the opinion that mass colonization in Siberia and Central Asia, which would permit several hundred thousands of colonists to be settled each year, is over. For some shorter period there are still some possibilities of an occupation for crops of new unoccupied land in Siberia and 
Central Asia. The Soviet government is planning to increase the crop area upon unoccupied land in Asiatic Russia during a fiveyear period on about 12 to 15 million hectares (30 to 37.5 million acres) ${ }^{6}$ but mostly in semi-dry regions of Central Asia. The better lands were taken by colonists even in these regions.

There are great possibilities of a better utilization for crops of already occupied agricultural area in European Russia as well as in Asiatic, because a large percentage of occupied arable lands in Russia are left idle as fallow or as temporary pasture (maybe up to 30 per cent), even in the regions densely populated. But a better use of arable land in Soviet Russia is connected with a complete reorganization of the existing agricultural system from a one-sided small grain production on the line of a traditional three-field system to a diversified farming with a smaller percentage of small grain crops. In such a manner the additional crop area on the previously idle crop lands would not result in a larger crop area under grain, but rather in an increase of forage, technical, and root crops. Thus, the grain area can not be substantially increased on account of a better utilization of actually occupied arable land in Russia. On the contrary, diversification of farming which may only permit better utilization of crop land, may result in a relatively smaller area under grain crops, because too high a percentage of small grain crops is typical of Russian agriculture. The tendency to a decrease of the percentage of grain crops may be observed just now. The total crop area increased during recent years in Soviet Russia mostly because other than grain crops were expanded and the percentage of grain area to the total crop area declined from about 90 per cent in 1916 to a little above 80 in 1929-30. The process of a diversification of farming proceeds rapidly in regions of the Ukraine and the North Caucasus, the most important for grain exports before the War.

This also answers the question of a possibility of an increase of grain production in the way of replacement of other crops. The tendency is just opposite, i.e., from small grains to other crops. There is some possibility of the expansion of the area of some particular grain, especially of wheat, on account of other small grains, but not of other than grain crops. Considerable expansion of wheat area is possible in the way of a replacement of rye by wheat, and such a tendency exists during recent years

\footnotetext{
- See the speech of the Commissary of Agriculture at the meeting of the 16th Congress of the Communist party, Pravda, July 12, 1930.
} 
and it is favored by the government. But such a shift from rye to wheat does not increase the exportable surplus of wheat because home wheat consumption must increase in order to replace the rye consumption. As to replacement by wheat of forage grains (such as oats and barley), it is scar ely probable because even now typical of Russia is the great predominance of breadgrains among all other grains. In Russia more than 60 per cent of the total grain area is under rye and wheat crops. Such relationship could exist only because the livestock industry of Russia, the feeding of animals, was upon a very primitive level. The natural tendency to expect in Russia is the increase of forage grain production for animal feeding, because the per capita consumption of forage grain for livestock was excessively low in Russia before the War as it continues to be now. The decline in the number of horses and their replacement by tractors is possible to some degree, which may lower the demand for oats, but on the other hand it is natural to expect a growth in the number of cattle and of swine and particularly the improvement of their feeding. This would require the increase of barley or corn production. The government plan for reorganization of Russian agriculture for recent years was directed to a development of the production of forage and of forage grain. Thus it is hardly probable that there will be a shift from forage grains to wheat. The normal tendency would be the opposite. Thus, the growth of wheat production for exports on account of a contraction (curtailment) of the forage grain area cannot be considered as probable for a longer period. It is possible that under the extreme pressure of a necessity to increase wheat exports, the government would try to shift from other grains to wheat, as was seemingly done in 1931 , but this may be considered only as a temporary phenomenon and the opposite tendency has to be expected from the point of view of a longer period.

As one of the possibilities to increase the grain production for exports in Soviet Russia is the raise of the yield per acre. The yield per acre of grains in Russia is so low that this gives some foundation to a speculation about a large growth of the yield of grain per acre in Russia during the near future. The plan of the Soviet government is to raise the yield of grain per acre by 35 per cent during five years. But there are too many difficulties which do not permit consideration of this plan as realistic. First, the climatic conditions of Russia are such-semi-dry climate in the most important grain-producing regions, particularly wheat 
regions-that it is impossible there to raise the yield of grain, particularly of wheat, to the level on which it is in the more humid regions of western Europe. The standard with which the yield per acre of grain in Russia may be compared is the yield of grains in the United States west of the Mississippi River, or in western Canada. But even this level gives considerable possibilities for a growth of the yield in Russia. During the pre-war time the yield of grain in Russia was not stationary but increased on the average by 1 per cent per year. Russian agricultural economists and statisticians during recent years (1926-28) considered the possibility of the growth of the yield by about 2 per cent per year, which corresponds to the growth of the yield in Germany during the last decades prior to the War, but only under conditions more favorable than those which existed at that time (1927-28) for Russian agriculture. ${ }^{7}$ To accept the possibility of a growth of the yield per acre by more than 6 per cent per year as the Soviet government plans would disregard all difficulties in the way of improvement of agricultural techniques and all historical experiences. For these reasons we consider this plan as only fantastic, and the results of the reorganization of Russian agriculture during recent years show that even if there are some achievements from the point of view of expansion of grain areas, there are no visible indications of substantial improvements of yields or of a lowering of costs. As to this last point (costs), we can not enter into a discussion of it because there are no reliable data available. But it is generally known that in all branches of Russian production, not only in agriculture, the expansion of production is not associated with lowering of costs. This is the weakest point in the execution of the Five-Year Plan. It is true that the monopoly of foreign trade, existing in the U.S.S.R., permits disregarding, at least for short periods, the losses on some particular exports, or rather to compensate them by gains on imports if the prices of imported manufactured goods are compared with possible costs of their home production. The state monopoly of foreign trade in Soviet Russia permits direct application to its foreign trade of the principle of comparative costs more rapidly and in a greater measure than it works in a competitive society, where this principle works only slowly and with considerable friction. But even

The rapid growth of the yield of wheat particularly is difficult to expect because the expansion of wheat production is mostly in southeastern semi-dry regions where the yield per acre must be lower than in the western part of the European Soriet Russia (Ukraine, North Oaucasus) because of the dry climate. 
disregarding the problem of costs there are some physical limits beyond which Russian grain exports can not be developed during short time periods. In addition to the limitation mentioned above there is of importance for a short time period the limitation of draft power existing in agriculture of Soviet Russia.

We hear abroad very much about a drastic effort of the Soviet government to increase the tractor power in Soviet Russia, but it is necessary not to forget that in 1930 there was in the U.S.S.R. a deficiency of from 5 to 6 million horses (that is 20 per cent below the pre-war number) and about 2 million oxen compared to the pre-revolutionary time (1916) on the same territory. This deficiency increased very much from 1929 to 1930 when a drastic campaign for a collectivization was organized by the government. The efforts to increase the mechanical draft power in agriculture in Soviet Russia are directed first to compensate for the enormous previous losses in animal draft power, and only after these losses would be compensated would it be possible to speak of a continuous increase of the grain production in Soviet Russia above the pre-war level in a substantial quantity. But only with such an increase would be possible the continuous recovery of the pre-war exports. For a short-time period the principal limitations for an expansion of grain production in Soviet Russia may be considered, therefore, the shortage of draft power and the difficulties in the reorganization of agricultural production on new lines (collectivization and state farming). ${ }^{8}$ For a long-time period the rapid growth of population, the inevitable tendency to shift from grain crops to other crops, and the comparatively limited resources of unoccupied arable land because of unfavorable climatic conditions in the greater part of Asiatic Russia would work against the growth of Russian grain exports. The tendency which existed even before the War for a more rapid increase of the interior market comparatively to the foreign would continue to work in Soviet Russia, particularly if the plan of industrialization should be to some degree successful. ${ }^{\ominus}$

\footnotetext{
S See my paper read in the joint meeting of the American Farm Economic Association and the American Statistical Association, December, 1930, Journal of Farm Economics, Vol. XIII, N. 2, April, 1931, pp. 280-304.

Produe points presented in this paper are developed in more detail in a study "Russia as a Producer and Exporter of Wheat" prepared for a forthcoming issue of "Wheat Studies," published by the Food Research Institute, Stanford University.
} 